\title{
The Development of Corporate Bond Markets: A Cross-Country
} Analysis

\author{
Dung P. Le ${ }^{1}$, Quang T. T. Nguyen ${ }^{1} \&$ Toan M. Nguyen ${ }^{1}$ \\ ${ }^{1}$ University of Economics, The university of Danang, Danang, Vietnam \\ Correspondence: Quang T. T. Nguyen, University of Economics, The university of Danang, 71 Ngu Hanh Son, \\ Danang, Vietnam. Tel: 084-913-041-479. E-mail: thieuquang.nt@ gmail.com
}

Received: November 8, 2015

Accepted: November 24, 2015 Online Published: December 25, 2015

doi:10.5539/ijef.v8n1p50

URL: http://dx.doi.org/10.5539/ijef.v8n1p50

\begin{abstract}
This study examines how macro-determinants influence corporate bonds by firms in 90 developed and developing countries over the period of 1970-2013. Employing Generalized Method of Moments (GMM) model, the study explores whether exchange rate variability and the openess of the economy have a significant impact on corporate bonds of firms. Specifically, it examines whether increased variability of exchange rates, increases the issuing of corporate bonds by the firms in these countries, or whether corporate bonds are used less by firms in countries where there is greater openness.
\end{abstract}

Keywords: corporate bonds, macro-economic variables, generalized method of moments (GMM)

\section{Introduction}

Corporate bonds have been widely used by firms to raise capital for business activities and debt financing, especially in the long run. It is also a common investment channel for investors who seek stable returns by holding bonds to maturity or high yield through trading bonds on the secondary market (Tendulkar \& Hancock, 2014).

The development of bond markets is the key for the efficiency of the economic system, besides the fact that it would bring more opportunities for investors and deepen the financial markets (Herring \& Chatusripitak, 2007). The existence of an effective bond market plays a crucial role in reducing financial sector fragility and provides an alternative cheap capital for firms (Yoshitomi \& Shirai, 2001). As can be seen from the financial crisis during 1997-1998 in Asia, one of the main causes was said to be the over-dependence of the economy on the banking system as these banks were highly regulated and were sensitive to the efficiency loss as well as the increased systematic risk.

Moreover, a robust bond market will help to modify the currency and maturity mismatches when long-term assets are financed by long-term liabilities; provide better tools for risk pricing due to the reduction of information asymmetry; enable efficient asset management and enhance the role of the country on the international capital markets (Plummer \& Click, 2005).

In terms of macroeconomic policy, a well-developed bond market not only provides useful market signals for the policy makers, but it is also a tool of financing fiscal deficits (Kahn, 2005).

As corporate bond markets have become an important channel of raising capital for the private sector since the mid-1990s, more and more efforts have been made to develop a deep, liquid and stable corporate debt market. With these important roles, global institutions, such as The International Monetary Fund (IMF), European Bank for Reconstruction and Development (EBRD) and Organization for Economic Co-Operation and Development (OECD), have recognized the needs of a sound development of corporate bond markets and consequently, built a joint "diagnostic framework" to promote and guide the development of these markets (IMF, EBRD \& OECD, 2013). Nevertheless, these markets remain under-developed relative to the banking system and equity markets in many countries, which is represented by the limited supply of quality issuance and inadequate market infrastructure (Luengnaruemitchai \& Ong, 2005; Smith \& Todd, 2005).

The study is designed to provide investors and policy-makers the underlying factors of the development of corporate bond markets, in terms of macro-determinants in order to develop these markets and guide them in making appropriate decisions. 
This study builds on this literature in two important ways. Firstly, because we consider these issues within a panel that includes firm fixed effects, we identify the issuing of corporate bonds in debt structure across countries that cannot be explained by cross-country differences in the firm-level characteristics. Secondly, we consider a larger number of countries and a number of macro-determinants not fully explored in this literature.

The paper is organized as follows: Section 2 presents and discusses the literature review, then Section 3 will introduces the data and the research methodology. Section 4 presents the results and findings and lastly, section 5 draws some conclusions and limitations.

\section{Literature Review}

Most studies about developing corporate bond markets was carried out in Asia, where the Financial Crisis 1997-1998 had the greatest affect (APEC, 1999; Sharma, 2001; Batten \& Kim, 2001; Fabella \& Madhur, 2003; Gyntelberg, Ma, \& Remolona, 2005; Eichengreen \& Luengnaruemitchai, 2004).

By studying the bond markets in developed countries, APEC (1999) summarized necessary characteristics for an effective bond market development and provided a guideline for APEC members to apply for their countries. These characteristics include sequencing (which referred to the plan of development), supervision and regulation to protect the investors, market infrastructure (which regarding rules, regulations, issuing procedures and the modus operandi of the market), and market deepening.

Sharma (2001) studied the corporate bond markets in Southeast Asia and pointed out that corporate sector and banking reforms, the enforcing of legal processes as well as enhancing the business transparency were necessary to increase the attractiveness of these markets. Besides, strengthening market infrastructure and improving the regulation related to bond issuance and its operations should also be focused.

Studying the bond markets in countries suffering from the Asian Crisis, Batten and Kim (2001) recommended these countries should focus more on providing enabling environment, enhancing corporate governance, increasing the role and reliability of credit ratings along with creating a benchmark yield curve, improving the investors' roles, widening private placement, providing real time delivery system and strengthening the regulatory framework in order to develop these markets.

Along the stream, Fabella and Madhur (2003) studied the bond market in East Asia and suggested that establishing a stable macro-environment and healthy government bond market besides completing the post-crisis agenda for restructuring the banking sector, improving corporate governance, enhancing the regulatory framework for this market, rationalizing the tax policy as well as broadening the investor base and providing incentives for the growth of regional bond market centers are necessary for these countries to be forward a sustainable bond market.

While studying the corporate bond markets in Asia, Gyntelberg et al. (2005) realized main obstacles to the development of corporate bond markets in this region. While primary markets depended on quasi-government issuers, the secondary markets suffered from narrow investor bases, insufficient microstructures and information asymmetry.

Eichengreen and Luengnaruemitchai (2004) is among the very few researchers who provided a comprehensive analysis about the factors of corporate financing through bond markets. These authors identified 15 determinants of the development of bond market including the economic size, the natural openness, the legal system, the geographical/disease endowments, the riskiness of the investment environment, the law and order, the weak corporate governance and transparency, the development stage of the economy, the size of the banking system, the banking concentration, the absence of public sector funding needs, the poor regulatory enforcement, the interest rate variability, the level of interest rates and the exchange rate regime. However, like above mentioned studies, this research is limited to Asia.

Nevertheless, the importance of the corporate bond market has been recognized and more and more efforts have been put on studying the development of this market in other regions of the world.

Ringui (2012) exploited factors of Kenya's corporate bond markets by considering the impact of the level of the corporate bond market development, the political, macroeconomic environment, supervisory and regulatory, effective market structures and diversified intermediaries. Conducting a structured survey on 60 listed firms on the Nairobi Securities Exchange, the author found that political environment of the country, investor base, regulatory framework, size of the banking sector, the cumbersome nature of issuance process as well as macroeconomic factors are important to the development of the corporate bond markets in Kenya.

Raghavan and Sarwono (2012) pioneered in India by conducting a research on determinants of corporate bond 
market in this country. Learning from experience of other countries where the corporate bond markets were well-developed, the authors identified and accessed the influences of: (i) the development stage of the economy, (ii) the natural openness, (iii) the size of the banking system, (iv) the size of the government bond market, (v) the development of the stock market and (vi) corruption index on the corporate bond market development. However, only the development of the government bond market and bank lending were found to be correlated with the growth of the corporate bond market.

Alegre et al. (2007) studied the development of corporate bond markets in Argentina by surveying firms and investors in this country. The paper showed that only large firms chosed bonds as a financing vehicle, which was rooted from the very few large firms in the survey country. The result also explained the underlying reason behind the relative small size of the Argentina corporate bond markets. IOSCO (2011) provided a deep inside about the corporate bond markets in Emerging markets through its surveys on 36 EMs in 2010. Realizing the hidden factors behind the under-development of these markets, which were characterized by poor quality bond offerings, small size of issuances and illiquidity secondary markets, the authors suggested that (i) prioritizing the development of corporate bond markets, (ii) improving market efficiency, (iii) enhancing market infrastructure, (iv) diversifying the investment instruments, (v) reducing risks for investors as well as (vi) building a conductive taxation framework should be regarded as key priorities by EM regulators in the efforts to develop corporate bond markets.

Among many studies in the corporate bond market field, only Tendulkar and Hancock (2014) provided a specific perspective of corporate bond markets in the world with evidence-base data. Not only analyzing the corporate bond market development, the report also identified issues and potential risks related to these markets to help guide further investigations. However, the relationship between these factors and the corporate bond markets development were not examined.

Macro-economic environment influences the bond markets through its impact on the capital flow and therefore the level of market liquidity. Fabella and Madhur (2003) pointed out that a stable and predictable macroeconomic environment would promote the development of the bond markets and conversely, it would need large supports from government.

This study investigates the effect of major financial and economic factors to the development of the corporate bond markets globally. These factors consist of the size of the economy, its natural openness, the size of the banking system and the exchange rate variability.

\subsection{The Size of the Economy}

Minimum efficient scale is crucial for a stable and large bond markets development. It was evidenced by Demirguc-Kunt (2005) that the small size is the main constraint that prevented emerging countries from raising fund abroad. The small amount of issuance in these markets may not be attractive enough to multinational corporations and potential foreign investors. The small size of the markets also makes it difficult to be reflected in the global bond market indices. Besides, it requires fixed costs to understand the characteristics of the markets. Therefore, there will be little demand for these local securities (Eichengreen \& Luengnaruemitchai, 2004). Hence, the relationship between the size of the economy and the corporate bond market development is expected to be positive.

\subsection{The Natural Openness of the Economy}

When the economy is open, entranced interests like banks will find it difficult to conduct policies that prevent competition from other sources of capital financing, and hence, the bond market will be less restrained. Consequently, the more the economy is open, the less it suppress the securities markets (Rajan \& Zingales, 2001).

\subsection{The Size of the Banking System}

While banks compete with bond markets in providing sources of financing, the existence of a large and well-developed banking system is vital for the development of the corporate bond market since banks serve as dealers and market makers for the smooth operation of this market (Baharuddin et al. 2011; Hawkins, 2002). The relationship between these two variables, therefore, is expected to be positive.

\subsection{The Exchange Rate Variability}

Investors tend to prefer an investment environment where the exchange rate is stable, as they have to face low risk (in terms of exchange rate risk). Therefore, it is argued that a less volatile exchange rate will promote the development of the bond market (Bhattacharyay, 2011). The correlation between these two factors, hence, is 
expected to be negative.

\section{Data and Methodology}

\subsection{Data}

Variables of the model as mentioned in the literature review include: the bond market size (represented by the bond issuance/GDP), the size of the economy (represented by the log of current GDP), the natural openness of the economy (represented by the export of goods and services/GDP), the size of the banking system (represented by the domestic credit of the banking system/GDP) and the exchange rate variability (represented by the percentage difference in the average exchange rate of the current and previous year).

Data on corporate bonds were collected annually from 90 countries for the period 1970-2013 from http://em.cbonds.com. Issuing amount in other currencies then was transferred into USD using the average exchange rate at the year of issuing. Except for the data related to the exchange rate, which was collected from the website www.fxtop.com, other macro-variables were gained from the World Bank.

\subsection{Methodology}

The variables were estimated using Generalized Method of Moments (GMM model). The regression model is as followed:

$$
\begin{gathered}
Y_{i t}=C_{i t}+\beta_{1} X_{1 i t}+\ldots+\beta_{n} X_{n i t}+u_{i t} \\
\left(i, t \in N^{*}\right)
\end{gathered}
$$

Where,

$\mathrm{i}=$ country, $1 \ldots 90$;

$\mathrm{t}=$ years, 1970-2013;

$\mathrm{Y}_{\mathrm{it}}=$ Total corporate bond market size in proportion to GDP of country $\mathrm{i}$ in year $\mathrm{t}$;

$\mathrm{X}_{1 \mathrm{it}} \ldots \mathrm{Xnit}=$ independent variables of country $\mathrm{i}$ in year $\mathrm{t}$;

$\mathrm{C}_{\mathrm{it}}=$ the constant for bond of country $\mathrm{i}$ in year $\mathrm{t}$;

$\beta_{1} \ldots \beta_{\mathrm{n}}=$ coefficients of the independent variables; and

$\mathrm{u}_{\mathrm{it}}=$ the independent normal distribution error terms with mean zero.

The GMM model is a common estimator in many areas of applied economics and finance and has been used widely by many researchers to study the development of the bond market. As a generalization of many other estimation methods such as Least Square (LS) method, Instrumental variables (IV) or Maximum Likelihood (ML) method the GMM model minimizes the bias of these models (Chaussé, 2010).

While estimating equation (1) using static panel model can occur bias and inconsistency, Arellano and Bond (1991) suggested to use variables in first differences and the use of the bond lags and its determinants at level as instruments. However, in case of persistent dependent variable, there will be high correlation of its values between the current and the previous period, which led the GMM estimator to be inefficient (Blundell \& Bond, 2000). Therefore, the instruments for variables at the level in the proposed equation (1) are variables lagged in first differences and reversely, instruments for variables in first differences are those lagged variables at level.

Though GMM is flexible and less likely to misspecific, it requires some assumptions about moment conditions to be robust: (1) the restrictions created as a consequence of using the instruments must be valid; (2) there is no second order autocorrelation (Krishnankutty \& Chakraborty, 2014). Hence, we use White test to eliminate the problem.

\section{Results and Discussion}

This section presents regressions that estimate the influence of country-level explanatory variables on corporate bonds, controlling for firm-level characteristics. Our regressions are estimated with a generalized method of moments (GMM) approach that accounts for the fact that the regression residuals are heteroskedastic and serially correlated across both firm- and country-level observations.

\subsection{Descriptive Statistic}

Table 1 reports the mean, standard deviation (STD), and number of observations (N) for all variables used in the paper. The sample consists of 90 countries from 1970 to 2013. Dependent variable is the corporate bond market size and independent variables include the size of the economy, the natural openness of the economy, the size of the banking system and the exchange rate variability, respectively. As can be seen from the table, these variables 
are significantly different among countries.

Table 1. Descriptive statistic of variables

\begin{tabular}{lccc}
\hline Variable names & Mean & STD & N \\
\hline Bond market size & $1.34 \mathrm{E}+09$ & $5.29 \mathrm{E}+09$ & 25585 \\
Size of economy & $7.39 \mathrm{E}+11$ & $1.63 \mathrm{E}+12$ & 25585 \\
Openness of economy & 45.60686 & 37.47929 & 25585 \\
Size of banking system & 340.3630 & 1946.027 & 25585 \\
Exchange rate variability & 0.065258 & 0.694615 & 25585 \\
\hline
\end{tabular}

To understand clearly how corporate bond markets differ from countries, we compute the mean and median of firm's bond issuance in the sample over the period 1970-2013. However, due to the large number of countries, we grouped them into continents: Europe, Africa, Asia, America and Oceania, respectively. As can be seen in Figure 1, it is obvious that countries in Africa had a quite developed corporate bond market with the average issuance above 0.08 million USD while Asia showed a weakness with just 0.023 million USD. Interestingly, although there were many developed countries in Europe, the development of corporate bond market in this area was slightly higher than that in Asia, evidenced by over 0.033 million USD. Nevertheless, median bond issuance in figure 2 shows a quite difference trend in which Oceania possessed the highest median amount of corporate bonds (about 0.06 million USD) and Africa ranked second with 0.04 million. Asia was still behind the growth with just 0.006 million USD of bonds.

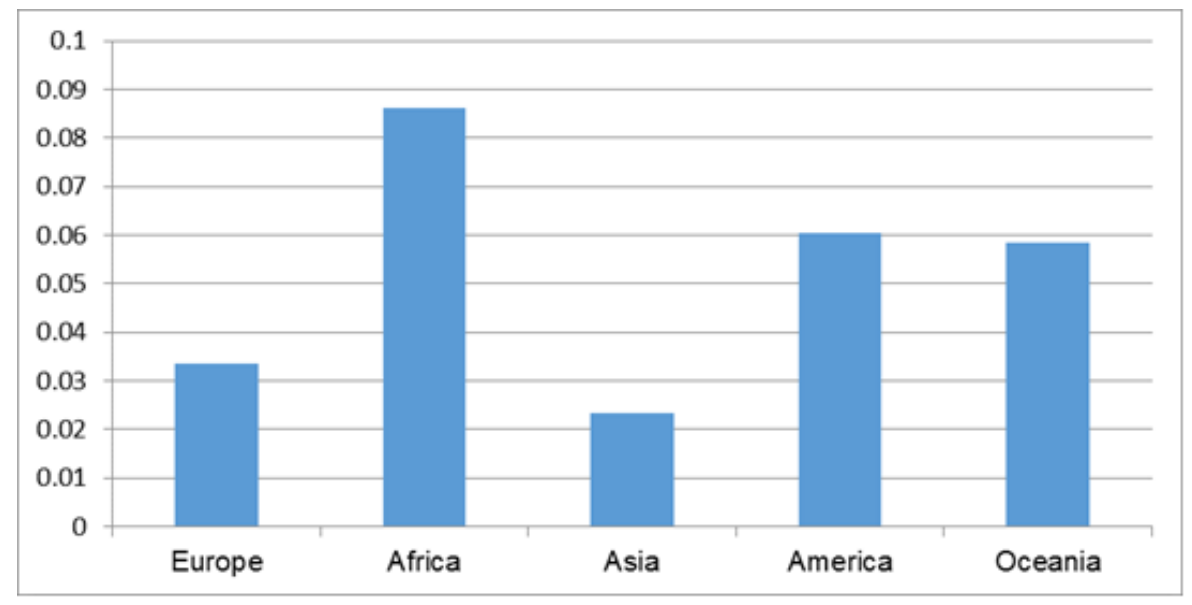

Figure 1. Mean corporate bond issuance across continents

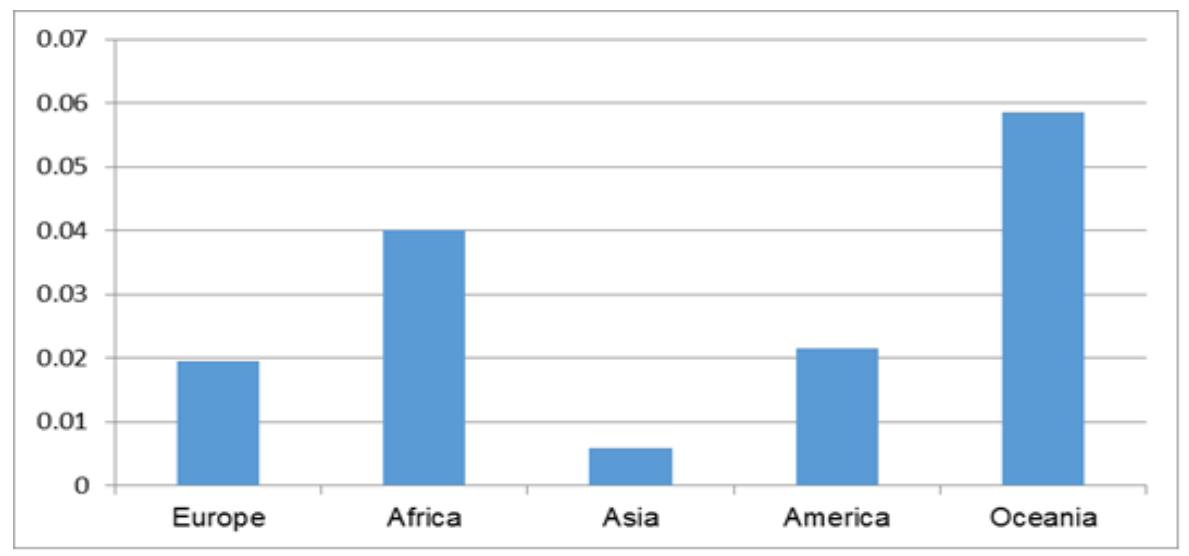

Figure 2. Median corporate bond issuance across continents 


\subsection{Regression Analysis}

Table 2 presents regression results about the effect of macro-determinants on the issuance of corporate bonds in the world. We estimate the model using GMM method. Robust standard errors clustered by country and by firm are reported in parentheses. Significance at the $10 \%, 5 \%$, and $1 \%$ level is indicated by *,**, and ***, respectively.

Table 2. Regression result

\begin{tabular}{lccc}
\hline \multicolumn{1}{c}{ Variables } & All sample & Developed countries & Developing countries \\
\hline Bond market size in & 0.257533 & 0.092013 & 0.418895 \\
previous period & $(0.011267)^{* * *}$ & $(0.034534)^{* * *}$ & $(0.004785)^{* * *}$ \\
Size of economy & 0.001162 & -0.000605 & 0.001251 \\
& $(0.001545)$ & $(0.000608)$ & $(0.000208)^{* * *}$ \\
Openness of economy & $-1.37 \mathrm{E}+08$ & 5726132 & 24118511 \\
& $(18724453)^{* * *}$ & $(3110769)^{*}$ & $(3825064)^{* * *}$ \\
Size of banking system & -12229008 & 349361.4 & -7031341 \\
& 22275023 & $(335883.4)$ & $(3746112)^{*}$ \\
Exchange $\quad 1.72 \mathrm{E}+09$ & $-4.72 \mathrm{E}+08$ & $2.50 \mathrm{E}+09$ \\
variability $\quad(6.05 \mathrm{E}+08)^{* * *}$ & Yes & $(1.47 \mathrm{E}+08)^{* * *}$ & $(69100633)^{* * *}$ \\
Country * time effects & Yes & Yes & Yes \\
Country $*$ firm effects & 90 & Yes & Yes \\
Number of countries & & 63 & 27 \\
\hline
\end{tabular}

It is obvious from the table that the openness of the economy and the exchange rate variability significantly affected the corporate bond market at $1 \%$ level. However, the effect was different from previous research and what we expected, in which the influence of the first factor was positive and the latter was negative.

The openness of the economy negatively affected the corporate bond market. This is interesting in the way that it is not necessary for an integrated country to have a well-developed bond market. The more opened a country is, the easier a company can raise funds. Corporates operating in these countries have greater choices in financing their business. Instead of restricting themselves to issuing bonds, they can borrow money from banks, issuing shares or even make international borrowings. Similarly, investors also find plenty of attractive and high-yield investment channels in these environments.

Besides, the corporate bond market was positively affected by the exchange rate variability. In other words, the more the exchange rate fluctuated, the more the corporate bond market developed. This could be explained by the fact that most issuances in the research were in domestic currencies; hence, the influence of the exchange rate was not significant. Nevertheless, once these companies promote issuing bonds in foreign currencies to attract capital from abroad, this effect must be put into consideration. Furthermore, the corporate bond markets still remain under-developed when compared to other markets such as equity markets in most countries.

However, when considering the developed and developing countries separately, there was evidence of inconsistent effects of macro determinants, which could be explained by the difference in the context of development of these countries from the history of the market, the transparency, the technology, the market structure to the regulatory framework.

Corporate bond issuance in developed countries were positively affected by the openness of the economy (at 10\% significant level) but negatively impacted by the instability of the exchange rate market (at $1 \%$ significant level). Despite the adverse trend in comparison with the whole sample, the effects were consistent with previous research (Rajan \& Zingales, 2001; Bhattacharyay, 2011).

Interestingly, all studied factors affected the development of corporate bond market in developing countries. Specifically, the size of the economy, the openness of the economy and the variability of the exchange rate impacted the corporate bond market positively while the effect of the size of the banking system was negative. In other words, for developing countries, the larger and the more opened the economy was, the more developed the corporate bond market became. This finding is similar to those of Demirguc-Kunt (2005), Eichengreen and Luengnaruemitchai (2004) and Rajan and Zingales (2001). Whereas, the banking system remained an obstacle for the development of corporate bond market in these countries. Companies in developed countries still preferred the traditional and easy to approach channel of financing and the investors still felt safer to invest into a 
financial institution rather than a corporate. These countries is highlighted by the poor capital market which make it difficult for small companies to raise fund.

Surprisingly, we found a positive correlation between the previous and the current bond issuance for all samples. This affect has not been explored in any previous researches. The bond financing of a corporate in the long run depends on the previous amount of issuance. Corporates planning for financing debt by bonds will consider their debt ratios before each announcement. Investors also act in the same way before putting their money into a specific bond. Therefore, information about corporate bond issuances as well as their details should be make transparent. This requires the important role of credit rating agencies associated with dependent supervisors. In addition, we do not find a significant relation between corporate bond and the size of economy, and the size of the banking system.

\section{Conclusions and Limitations}

There are rich empirical evidences supporting the relationship between corporate bonds and firm characteristics. Yet little is known about how macro-variables affect corporate bonds. The aim of this paper is to enhance our knowledge of these matters by examining the corporate bonds with macro-determinants on the development of these markets globally. The significance of the paper first shows at its research scale that was 90 countries in a relative long period from 1970 to 2013. Moreover, the paper includes a number of factors that are not fully explored in previous studies to determine their long-run and the general effects as well as individual effects on corporate bond markets. By applying GMM method, the result revealed that while the openness of the economy had negative influence on the corporate bond market, the impact of the exchange rate variability was positive and no correlations between the size of the economy as well as the size of the banking system and the corporate bond market development had been found. Furthermore, we also found that the bond issuance amounts in the current year was affected by that in the previous period. The general effect was quite in favour of the group effect of the sub-sample for developed countries as these constituted the most percentage. Collectively, our results identified macro factors as important determinants of firm debt structure and shed new light on a channel through which the openness of the economy and the exchange rate variability influenced firm corporate bond decisions.

However, there are still some limitations to the study. First, the development of the corporate bond markets not only depends on the macro-determinants, but also on other variables such as company-level or market-level determinants. Not taking into account the correlation between these variables; therefore, the research might not fully assess the effect of these variables on the development of the corporate bond markets. Second, the research was carried out on a quite large sample, which induced the unavailable of some determinants. Thus, there were only four macro-determinants investigated. In the future, with the development of the database and the background of the research, the expansion of variables may be considered to provide a better assessment of the issue.

\section{References}

Alegre, M., Pernice, S., \& Streb, J. M. (2007). Determinants of the development of corporate bond markets in Argentina: Survey to firms and investors. Documento de Trabajo, no. 345.

Arellano, M., \& Bond, S. (1991). Some tests of specification for panel data: Monte Carlo evidence and an application to employment equations. The Review of Economic Studies, 58(2), 277-297. http://dx.doi.org/10.2307/2297968

Baharuddin, N. S., Khamis, Z., Mahmood, W. M. W., \& Dollah, H. (2011). Determinants of Capital structure for Listed Construction companies in Malaysia. Journal of Applied Finance and Banking, 1(2), 115-132.

Batten, J., \& Kim, Y. H. (2001). Expanding long-term financing through bond market development: A post-crisis policy task. Government bond markets in Asia, 290-360.

Bhattacharyay, B. N. (2011). Bond market development in Asia: An empirical analysis of major determinants.

Blundell, R., \& Bond, S. (2000). GMM Estimation with Persistent Panel Data: An application to Production Functions. Econometric Reviews, 19(3), 321-40. http://dx.doi.org/10.1080/07474930008800475

Chaussé, P. (2010). Computing Generalized Method of Moments and Generalized Empirical Likelihood with R. Journal of Statistical Software, 34(11), 1-35. http://dx.doi.org/10.18637/jss.v034.i11

Demirguc-Kunt, A. (2005). Cross-Country Empirical Studies of Systemic Bank Distress.

Eichengreen, B., \& Luengnaruemitchai, P. (2004). Why doesn't Asia have bigger bond markets? National Bureau of Economic Research. http://dx.doi.org/10.3386/w10576 
Fabella, R., \& Madhur, S. (2003). Bond market development in East Asia: Issues and challenges. Asian Development Bank.

Gyntelberg, J., Ma, G., \& Remolona, E. M. (2005). Corporate bond markets in Asia. BIS Quarterly Review, December.

Hawkins, K. (2002). Law as last resort: Prosecution decision-making in a regulatory agency. Oxford University Press.

Herring, R. J., \& Chatusripitak, N. (2007). The case of the missing market: the bond market and why it matters for financial development. Recent Financial Crises: Analysis, Challenges and Implications, p. 148.

IOSCO. (2011). Development of Corporate Bond Markets in the Emerging Markets. Report by Emerging markets committee of the International Organization of Securities Commissions in collaboration with the World Bank Group, FR10/11, November 2011. Retrieved from http://www.iosco.org/library/pubdocs/pdf/IOSCOPD360.pdf

Kahn, B. (2005). Original Sin" and bond market development in Sub-Saharan Africa. Africa in the World Economy: The National, the Regional and International Challenges, The Hague: Fondad, pp. 67-87.

Krishnankutty, R., \& Chakraborty, K. S. (2014). The Determinants of Corporate Debt Maturity: A study on listed companies of Bombay Stock Exchange 500 index. Romanian Economic Journal, 17(51), 67-90.

Luengnaruemitchai, P., \& Ong, L. (2005). An anatomy of corporate bond markets: Growing pains and knowledge gains.

Plummer, M. G., \& Click, R. W. (2005). Bond market development and integration in ASEAN. International Journal of Finance \& Economics, 10(2), 133-142. http://dx.doi.org/10.1002/ijfe.268

Raghavan, S., \& Sarwono, D. (2012). Development of the Corporate Bond market in India: An Empirical and Policy Analysis. Paper presented at International Conference on Economics and Finance Research IPEDR.

Rajan, R. G., \& Zingales, L. (2001). Financial Systems, Industrial Structure, and Growth, Oxford Review of Economic Policy, 17(4), 467-482. http://dx.doi.org/10.1093/oxrep/17.4.467

Ringui, J. K. (2012). A survey of factors determining development of corporate bonds market in Kenya. School of Business, University of Nairobi.

Sharma, K. (2001). The Underlying Constraints on Corporate Bond Market Development in Southeast Asia. World Development, 29(8), 1405-1419. http://dx.doi.org/10.1016/S0305-750X(01)00043-2

Smith, J. A., \& Todd, P. E. (2005), Does Matching Overcome LaLonde's Critique of Nonexperimental Estimators? Journal of Econometrics, 125(1), 305-353. http://dx.doi.org/10.1016/j.jeconom.2004.04.011

Tendulkar, R., \& Hancock, G. (2014). Corporate Bond Markets: A Global Perspective. Staff Working Paper of the IOSCO Research Department. IOSCO. April 2014. Retrieved from http://www.iosco.org/research/pdf/swp/SW4-Corporate-Bond-Markets

Yoshitomi, M., \& Shirai, S. (2001). Designing a financial market structure in post-crisis Asia. ADB Institute Tokyo.

\section{Copyrights}

Copyright for this article is retained by the author(s), with first publication rights granted to the journal.

This is an open-access article distributed under the terms and conditions of the Creative Commons Attribution license (http://creativecommons.org/licenses/by/3.0/). 